\title{
Wahkohtowin in Action
}

\section{Matthew Wildcat*}

\section{Introduction}

From a Canadian legal standpoint, a common concern expressed about Indigenous law is that it is difficult to track down. As Hadley Friedland summarizes, "even people who want to engage more deeply with Indigenous legal traditions struggle to understand how to do so." In response, Friedland has proposed a case law method that allows Indigenous communities and legal practitioners to access Indigenous law. ${ }^{2}$ I believe the case law method can be valuable, but I hope to provide an illustration of the operation of Indigenous law by looking at how the Cree/Metis principle of wahkohtowin was infused through the work of the Maskwacîs Education Schools Commission (MESC). My work here does not attempt to describe in full how wahkohtowin operates as a legal principle within Maskwacîs. Rather, I focus on the central role wahkohtowin played in the largest institutional transformation the community has ever undertaken.

The MESC was set up to explore the potential amalgamation of the school systems of four First Nations: Montana, Louis Bull, Ermineskin, and Samson. The process came with a new funding agreement with the Federal Government and removes the schools from the authority of the Indian Act. ${ }^{3}$ These Nations are all part of the Plains Cree community of Maskwacis and have reserve lands that border one another. Currently each Nation operates its own school system, but the past nine years have seen increasing cooperation among them. This cooperation resulted in a community-initiated process to explore the creation of a unified Maskwacîs school system.
Indigenous peoples face two large obstacles in transforming our legal and political orders. First Nation governments tend to focus on how they provide services independent of other political authorities. Displays of independence are important when positioned against Canadian authorities given the history of Canadian governments intervening and imposing their authority on First Nations. But First Nations often position their authority against each other. Rather than emphasize how different First Nations might share authority with each other in the pursuit of providing services, First Nations tend to emphasize their independence when thinking about how to offer services. These dynamics are amplified by the conditions of living within an ongoing settler-colonial state.

Second, political and legal traditions within Indigenous communities at times conflict with each other and this becomes apparent when we attempt to make decisions collectively. In particular, within the process I will describe how a conflict emerged from our focus on wahkohtowin that led us to emphasize cooperation and a discourse on Treaty rights that warns people that the large institutional transformation that MESC undertook may result in the erosion of such rights. In this situation, the obstacle is that we do not have regular venues to decide what principles we want to prioritize when facing major decisions.

The above obstacles - an understandable emphasis on independence in light of ongoing settler colonialism, and a lack of venues to sort through conflicting principles that arise when we make collective decisions - tend towards the maintenance of the status quo. However, in the face of these obstacles, the work of the Com- 
mission has ended with the creation of a unified school system for the upcoming 2018-19 school year. In this essay, I detail how wahkohtowin played a central role in the deliberations around whether to amalgamate the school systems. I begin by defining the concept of wahkohtowin, before offering a brief history of Early Childhood to Grade 12 education in Maskwacîs. Next, I expand upon the two barriers that prevent the transformation of our legal and political orders described above and show how prioritizing a discourse of wahkohtowin was integral to ensuring the process was community-driven and not just a reaction to the Federal government.

\section{Wahkohtowin}

Wahkohtowin directly translates to English as kinship or being related to each other. ${ }^{4}$ But the concept encompasses a wider set of ideas about how things are related within Cree worldviews. I break down the meaning of wahkohtowin into three parts. First, it references the act of being related - to your human and other than human relatives. Second, it is a worldview based on the idea that all of existence is animate and full of spirit. Since everything has spirit it means we are connected to the rest of existence and live in a universe defined by relatedness. Third, there are proper ways to conduct and uphold your relationships with your relatives and other aspects of existence. Thus, wahkohtowin also includes the obligations and responsibilities people have to maintain good relationships.

Other Cree and Metis writings about wahkohtowin delve deeper. The late Cree intellectual Harold Cardinal, writing with Walter Hildebrand, describe wahkohtowin as the "laws governing all relations". ${ }^{5}$ Falling under wahkohtowin is the doctrine of miyo-wicehtowin, the "laws concerning good relations", ${ }^{6}$ which sums up this Cree way of thinking about how to live lawfully in the world:

Miyo-wicehtowin is a Cree word meaning 'having or possessing good relations.' ... It asks, directs, admonishes, or requires Cree peoples as individuals and as a nation to conduct themselves in a manner such that they create positive or good relations in all relationships, be it individually or collectively with other peoples. ${ }^{7}$

In Sylvia McAdam's book on Cree law, entitled Nationhood Interrupted: Revitalizing nêhiyaw Legal Systems, ${ }^{8}$ she describes wahkohtowin as "crucial in understanding how nêhiyawak regard relationships as the foundation to their ties to everything, including creation." 9 McAdam quotes her father Francis McAdam Saysewahum:

Long ago after the human beings were created, they were allowed to walk with the animals and talked amongst each other like relatives. Even the trees, plants, all manner of life was able to communicate with each other. That was the beginning of understanding wâhkôtowin and the laws surrounding it... . We still remember we are related to all of creation, that is still followed to this day. ${ }^{10}$

Finally, the Metis elder Maria Campbell's description of wahkohtowin is worth quoting at length:
There is a word in my language that speaks to these issues: 'wahkotowin.' Today it is translated to mean kinship, relationship, and family as in human family. But at one time, from our place it meant the whole of creation. And our teachings taught us that all of creation is related and inter-connected to all things within it.
Wahkotowin meant honoring and respecting those relationships. They are our stories, songs, ceremonies, and dances that taught us from birth to death our responsibilities and reciprocal obligations to each other. Human to human, human to plants, human to animals, to the water and especially to the earth. And in turn all of creation had responsibilities and reciprocal obligations to us. ${ }^{11}$

Thus, wahkohtowin encompasses the act of being related, a worldview that everything is related, and a set of laws or obligations around how to conduct good relationships. ${ }^{12}$

References to wahkohtowin have increased recently, from both an institutional and scholarly standpoint. I grew up within the shadow of Miyo Wahkohtowin Education Authority, where my father Brian Wildcat has been superintendent for the vast majority of its 26 years of operation. My workplace, the University of Alberta, has 
various references from the wahkohtowin conference (the inspiration of this special issue), to the wahkohtowin project and the wahkohtowin lodge at the Augustana campus. ${ }^{13}$ Various other institutional spaces also reference wahkohtowin, from the Wahkohtowin - Strengthening Families Program, ${ }^{14}$ Wahkohtowin Child and Family Services Inc., ${ }^{15}$ The Saddle Lake Wahkohtowin Society, ${ }^{16}$ and Wahkohtowin Development Corporation. ${ }^{17}$

Wahkohtowin is also used to guide and inform research projects. The most ambitious of these undertakings has been Brenda MacDougall's One of the Family, ${ }^{18}$ detailing kinship connections in the Île-à-la-Crosse region of Saskatchewan over four generations in the $18^{\text {th }}$ and early $19^{\text {th }}$ century. In Saskatoon, a group of teachers made wahkohtowin central to a class they cotaught. They comment on the learning space they created, observing that " $[t]$ he Wahkohtowin class embraces a commitment to healthy relationships as justice in action, and aims to enact the restoration of right relations through our pedagogy." 19 Another group of researchers argue for the use of wahkohtowin as a research methodology:

\footnotetext{
Because we were keenly aware that our research must be accountable to the participants in our project, we wanted to develop an academic discourse that valued and respected Indigenous epistemology. As a result, we based our research methodology on the concept of wâhkôhtowin. 'Wâhkôhtowin', a Cree word meaning kinship or the state of being related, is a fundamental concept for understanding Indigenous culture and traditional beliefs because it highlights the importance of community. ${ }^{20}$
}

While not directly related, it is also worth mentioning the growing body of scholarship which has suggested that the Northwestern plains were governed by "multicultural" regional political formations based around kinship prior to the rise of settler colonialism. ${ }^{21}$

This scholarship suggests that concepts and philosophies focused on kinship, such as wahkotowin, were a central aspect of ordering political authority within the Plains Indigenous political order prior to the rise of settler society. This scholarship only adds to the picture of what Plains
Indigenous peoples already know from lessons passed down within families and communities; building and maintaining good relationships is integral to any just political community.

\section{First Nation Control of Education in Maskwacîs}

The First Nations of Maskwacîs signed an adhesion to Treaty Six in 1877 at Blackfoot crossing, located today on Siksika First Nation. Part of Treaty Six states that "Her Majesty agrees to maintain schools for instruction in such reserves hereby made as to Her Government of the Dominion of Canada may seem advisable, whenever the Indians of the reserve shall desire it." ${ }^{22}$ People within Maskwacîs today refer to this clause as the treaty right to education. The earliest form of schooling in Maskwacîs was the establishment of the Ermineskin Residential School in 1916. During its early operation, school children were not allowed to return home during the school year even though most students lived within walking distance of their parents. The residential program of the Ermineskin school closed in $1975 .^{23}$

In 1971, parents at Blue Quills School in Saddle Lake staged a sit in at the school. They demanded that control of the schools be handed over to Saddle Lake First Nation. This action initiated the devolution of local control to First Nation schools. ${ }^{24}$ In Maskwacîns, the four Nations gained local control of their schools between 1989 and 1996. This period was also accompanied by the building of eight different schools completed between 1993 and 2006. Most importantly, the building of First Nation run school systems resulted in the overall improvement of the schools, as evidenced by a gradual increase in enrollment over the past 25 years. In 1990, only one-third of school age children in Maskwacîs went to school on-reserve. Today two-thirds of school age children go to school on-reserve..$^{25}$

The MESC originally began as the Maskwacîs Education Steering Committee in 2011. The Committee was set up to "discuss issues of concern to all of the Four Nation schools and administer" a federal granting program on behalf of the four school systems. ${ }^{26}$ The formal creation of the 
MESC was built upon significant informal collaboration that had been occurring in the years leading up to 2011. In 2012, the Maskwacîs Outreach School was created and was administered by the Maskwacîs Education Steering Committee working in collaboration with the existing school systems in Maskwacîs.

In the spring of 2015, planning meetings were held to discuss the long-term future of education delivery in Maskwacîs. Different options were created for how best to move forward with the future of Early Childhood to Grade 12 education. It was determined that the best option was to explore the potential of merging the four school systems into a unified entity. This would create one of the largest First Nation school systems in Canada with 11 schools and approximately 2300 students. A leadership summit was held in May 2015 with Chief and Councils of all the Maskwacîs nations where the proposal was tabled. At the meeting, the atmosphere in the room was one of uncertainty. The room, however, swung in favour of moving forward with exploring a potential merger of the four school systems after an impassioned plea by Chief Darrell Strongman asking everyone to focus on what is best for the children. ${ }^{27} \mathrm{~A}$ motion was passed at the end of the meeting that read:

Be it resolved that we, the Maskwacîs Cree Chiefs and Council, direct the Maskwacîs Education Steering Committee to investigate the possibility of developing Maskwacîs Education Authority that meet the following criteria/principals/ conditions:

1. Treaty based

2. Guaranteed funding for the process

3. Adequate time frame; and further that, proper protocol be conducted to commence the process.

In early 2016, the MESC was incorporated so it could receive the necessary funds to explore the amalgamation. ${ }^{28}$ Since that time the pace of the work has moved swiftly. From November 2017 to December 2017 five leadership summits and twenty-four community meetings were held.
I participated in all of the leadership summits and the early community meetings in my role as a communications and governance advisor for the MESC. During our community meetings, we administered approximately 1300 surveys about the process. Our final question asked, "Do you support the proposed amalgamation?" The positive reaction was an overwhelming 92 percent in favour of the amalgamation process. ${ }^{29}$

The Maskwacîs Education Schools Commission Resource and Development Agreement was signed between the Chiefs of Maskwacîs and Canada's Minister of Indigenous Services in May 2018. A 2013 study estimated that on average, students at First Nations schools receive 30 percent less funding per student than a comparable student at a provincial school. ${ }^{30}$ Recent steps have been taken to end the funding gap, but they are only half measures. The Maskwacîs Education Agreement ends this discrepancy by creating a funding agreement that uses provincial funding formulas where appropriate, eliminating proposal-driven funding, and providing additional transition dollars to help improve the school system. In short, there will no longer be a funding deficit for Maskwacîs schools.

\section{Barriers to Cooperation}

The work of the MESC was very successful in fostering cooperation in a political climate where cooperation is notoriously difficult. Within the prairie Indigenous political order, it is difficult for First Nations to share authority with each other around the delivery of services like education, healthcare, social services, law, housing, and infrastructure. To understand the MESC's success, we have to understand the structural conditions of Indigenous governments that make such cooperation difficult, and how these structural conditions operate at the level of political discourse.

\section{Indigenous Governments and Shared Authority}

A number of structural elements exist today that prevent cooperation between Indigenous nations. Approaches to First Nations govern- 
ments tends to focus on the internal operation of these governments. In other words, studies tend to take a unit level analysis - with the unit being an individual First Nation government. My research, on the other hand, is primarily concerned with a system level analysis, or how First Nations governments are positioned in relation to one another. In the following I focus on political authority and citizenship.

This theorization of Indigenous political authority and citizenship emerges from a history of Anglo states attempting to domesticate Indigenous peoples, in part by imposing centralized, "representative" bodies onto Indigenous nations and communities. The creation of Indigenous governments means that former political institutions are effaced or transformed, and political authority is deposited in an Indigenous government. ${ }^{31}$ Other sources of Indigenous collective authority continue to be enacted but they are marginalized or excluded from representation within state legal systems. ${ }^{32}$

The moves that funnel Indigenous political authority into centralized representative bodies have two functions for settler states. First, these bodies become the vessels that receive the recognition that the state bestows on Indigenous collectives. Second, political assent can be extracted from these bodies to legitimate the presence and activities of settler societies over Indigenous lands. When conducting negotiations with Indigenous governments, settler states attempt to impede Indigenous claimants from overlapping jurisdictional claims. For example, in Tsilhqot'in Nation $v$ British Columbia ${ }^{33}$ Chief Justice McLachlin states that Aboriginal title must have three characteristics: "it must be sufficient; it must be continuous (where present occupation is relied on); and it must be exclusive." 34 Part three of the test, which requires occupation at sovereignty to have been exclusive, ${ }^{35}$ is of importance here. McCrossan and Ladner argue that the Tsilquot'in Nation judgement is a continuing settler-colonial commitment to eliminate alternate legal orders and spaces of Indigenous jurisdiction. ${ }^{36}$ Entrenching exclusivity within the Aboriginal title test cuts across Indigenous legal orders where it was "not terri- torial exclusivity that was privileged, but rather responsibility as it is the absence of rights and the presence of an underlying philosophy of responsibilities that remains central within Indigenous traditions." ${ }^{37}$ Daniel Voth has also shown how Aboriginal title litigation in southern Manitoba funneled the Manitoba Metis Federation and Treaty 1 peoples into "divisive, exclusionary, zero-sum political relationships between Indigenous peoples." ${ }^{38}$

In regard to citizenship, Indigenous governments have moved to a situation where they have a stable membership. Indigenous individuals with Indian status in Canada can only hold membership in one First Nation - a phenomenon I refer to as singular band membership. Although the membership of a First Nation is often comprised of people from many cultural groups, First Nations typically prioritize an affiliation with only one cultural group. ${ }^{39}$ These ideas about membership and territory can be traced to policies enacted by settler governments, but many of these ideas are now championed by First Nation political leaders themselves. ${ }^{40}$ The standards used by the Bureau of Indian Affairs in the United States helps to illustrate the logic behind singular membership. The following criteria are used to evaluate Indigenous communities seeking federal recognition:

[T]he membership of the tribe 'comprises a distinct community' that 'has existed as a community from historical times until the present.' ... [I]ts membership includes 'individuals who descend from a historical Indian tribe or tribes, which combined and functioned as a single autonomous political entity.' ... [T] he membership is unique and does not include individuals who are members of other recognized tribes. ${ }^{41}$

Of course, most Indigenous communities have kinship relations with other communities that complicate the practice of singular band membership. A large percentage of status Indians do not live on the reserve where they hold membership. The mobility pattern we often assume for people who do not live on their reserve is that they move to cities. But reserves also have a small but significant number of residents who have 
membership in another First Nation. This complicates not only questions of membership, but also of how membership attaches to the political jurisdiction held by Indigenous governments. Many have also shown how singular band membership negatively impacts women and their children. ${ }^{42}$

Today, Indigenous governments hold their authority in exclusion to each other. Even though Indigenous governments hold political authority independent of each other, choices over where to maintain independence and where to engage in collaboration must be made by political leaders. Indigenous governments are fairly willing to collaborate over externally focused relationships with settler governments, but much less collaboration occurs over how First Nations conduct activities like education, healthcare, and social services. For example, in the area of education only two entities exist that provide education for multiple First Nations. In the area of children's services, there are 17 delegated First Nation agencies. Eight of these agencies only serve a single First Nation and two other agencies serve First Nations that border each other, one being in Maskwacîss and the other working on behalf of the Stoney First Nations. Of the remaining seven agencies, five of them are in Treaty Eight territory, where populations tend to be much smaller. $^{43}$

Historically, the amalgamation of First Nation communities was an idea put forward by the Royal Commission on Aboriginal Peoples (RCAP), which envisioned the 633 First Nations in Canada amalgamating themselves into 50-80 Nations that would exercise self-government. ${ }^{44}$ As Belanger and Newhouse explain, "RCAP delineated self-government as a right dependent upon an Aboriginal peoples' claim to nationhood, limiting further what peoples were able to claim this right." ${ }^{45}$ The RCAP also saw their national governments as being set up within a federated structure similar to Canadian Confederation, with the regional government holding certain authorities and community governments exercising authority in other areas. The RCAP proposal was viewed as another outside imposition defining how Indigenous peoples should exercise governmental powers. The prescriptive nature of who could exercise self-government in RCAP was also an affront because Indigenous political leaders had spent the last 25 years arguing that self-government was an inherent right that flowed from Indigenous peoples' sovereignties, not from rights granted by Canadian law. While further work is needed, my speculation is that this episode has meant that all proposals where separate First Nations would pool or aggregate their authority are now viewed as an agenda being driven by the Federal government and not by Indigenous decision-making processes. In other words, we view changes where First Nations share authority with each other as a transition that undermines the sovereignty of Indigenous peoples.

This plays into another difficulty of First Nation collaboration. There is still a general fear that increased collaboration will be used by Canadian governments as an indication that First Nations are not sovereign and that this will be used to undermine treaty rights. Speaking about Indigenous governance in Canada requires traversing a difficult and often hostile discursive space. For Indigenous peoples, when speaking about the challenges and issues facing Indigenous governance, there is a concern that those words will be used against us by antagonistic elements of settler society. Yet, discussing the ways settler colonialism has impacted Indigenous political orders requires us to discuss some of the various ways that First Nation governments perpetuate dysfunctional dynamics today.

To do so ethically requires articulating the role settler society plays in perpetuating these dysfunctions in the present so it is clear that the forms of governance are not the result of Indigenous pathology. Drawing on the work of Audra Simpson, I have discussed elsewhere how Indigenous communities embody a collective effect that is literally afraid of our collective death - a phenomenon I refer to as the "fear of social and cultural death." ${ }^{46}$ Our anxieties about social death motivate us to take political positions that protect our sovereignty from dominant discourses that still do not treat Indigenous sovereignty as legitimate. Thus, any move where a First Nation might 
share or pool authority with each other has the potential to undermine Indigenous sovereignty because it must travel through discursive fields where hostile elements of settler society can be inclined to argue that First Nations are not really sovereign if they cannot administer services on their own.

This thinking also applies to working with provincial governments, the thought being that because the provinces did not sign treaties, interacting with them will diminish treaty rights because it will absolve the federal government of its treaty responsibilities. Again, this was a policy proposal of the Federal government in the 1960s when it tried to offload responsibilities for status Indians onto the provinces. ${ }^{47}$ Today, many First Nations are hesitant to even have conversations with provincial governments over areas like education and child welfare.

Although it is important to take a long view of how Canada has attempted to undermine and limit the scope and reach of Indigenous sovereignty, creating blanket directives such as prohibiting discussions with provinces about areas of shared concern or not allowing First Nations to create shared authorities with each other shuts off potential avenues that can have real material benefits in our communities. The actions we undertake to protect our sovereignty can often have unintended and negative consequences that limit cooperation amongst First Nations and other sites of Indigenous collectivity.

\section{Treaty rights and wahkohtowin}

When the MESC embarked on its work beginning in the summer of 2016, there was a general sense that people would be suspicious and hesitant about the proposal. There were two issues we thought would arise. The first was a lack of trust in Chief and Council to make decisions in the best interest of the community. Second was a concern that undertaking the amalgamation would result in a loss of the treaty right to education. The first concern was expressed at community meetings but never became a prominent concern or point of reference within the process.
Protecting treaty rights, however, played a prominent role throughout the process. How we protect treaty rights was expressed in different ways, but all articulations would have required Maskwacîs to stay with the status quo. There were essentially three approaches. In the strictest sense, the "protecting treaty rights" discourse posits that any situation where treaty Indigenous peoples trade the status quo for a different set of rights or agreements will erode treaty rights unless natural law is fully recognized and made operational within Canadian society. The second articulation deals with delegation. This articulation asserts that treaty rights are held by First Nations. Thus, protection and stewardship of treaty rights are the responsibility of the First Nation Chief and Council. The amalgamation process would require that Chief and Council delegate their authority to an amalgamated Maskwacîs entity. The delegation process already occurs for any First Nation that has an authority operating their school system on their behalf. The difference would be the delegation to an entity that acts on behalf of multiple First Nations. Since First Nations would not have exclusive control over their school systems, they could, by delegating, undermine the responsibilities they have to hold and implement treaty rights.

The final articulation was that the federal government intentionally sought to initiate legislative and policy changes to erode treaty rights. Or closely related, the federal government will take advantage of any moment of flux or change to erode treaty rights in an underhanded way. This line of argumentation works in concert with Chief and Councils needing exclusive control of treaty rights in order to protect them. Any change in structure or agreement provides an opportunity for the further erosion of treaty rights. With each of these three articulations or approaches, the idea is that we need to guard against the erosion of treaty rights by not dealing with the federal government.

Instead of derailing the process, the MESC also focused on two other principles that played a prominent role in all our deliberations - a focus on doing what is best for children and wahkohtowin. When our discussion revolved around 
these issues it became clear that we needed to focus not on issues of jurisdiction or the Federal government, but on what was best for the children in the community. As well, because we have a history of success, we felt confident in our ability to create a school system focused on wahkohtowin, students, Cree knowledge, and community priorities.

As noted above, the concept of wahkohtowin played a central role throughout the work of the MESC. Without a focus on wahkohtowin we would not have had the capacity to work against the dynamics that prevent Indigenous cooperation outlined above. Although others may disagree, my perception is that wahkotowin remains well understood within the community as a philosophical concept. When drafting foundational statements, the Commission stated that "MESC operates and makes all decisions following the guiding principle of wahkotowin based on the fact that all Maskwacîsak are related and connected to each other and reside on traditional Maskwacîs territory." 48

In an informational video profiling the schools' principals, Samson Cree Nation member and Assistant Principal, Tracy Swampy, also describes the importance of wahkohtowin:

The guiding principle for MESC I believe is wahkohtowin, and wahkohtowin means ... relationships and kinship. And I believe that because we are the four nations and we all have relatives on the four nations, it would be amazing for us to get together and share all of the knowledge from each community, sharing the language, the traditions, the teachings, the culture, it would strengthen our community even more, and I believe for the kids to be in a school system that would involve all four nations, they would meet their relatives, they would learn from the communities around us, we wouldn't be seen as four nations divided, we would be one big nation together and I believe that's very important for a strong community. ${ }^{49}$

Within the process we also created a Maskwacîs Declaration on Education. I was the main facilitator of the process and helped to draft the document based on a workshop held in February 2017 and through a review process by the MESC
Board, Committee of Elders, and Maskwacîs Council. The Declaration states:

To guide our actions, we will follow cultural and traditional teachings, in particular Wahkohtowin. Wahkohtowin is the belief that all things are related and connected, that all of existence has spirit and that living in a good way requires us to maintain good relationships with each other and other aspects of existence. ${ }^{50}$

Finally, wahkohtowin even arose unprompted within our community engagement. We held a Facebook contest asking community members to "[d]escribe a Cree word you think is important to teach in our schools." The winner, Louisa Rain, provided a quote from her late Mother, Josephine Thompson Rain: "Wahkohtowin is a vital part of the Cree Culture. Wahkohtowin reinforces family roles and responsibilities thereby strengthening family ties and fostering a development of healthy families and good relations." ${ }^{51}$

Finally, we began to refer to our governance structure as a wahkohtowin-inspired governance model. This is because the model ensures that overarching board governance decisions on the direction of the schools are the result of multiple groups of peoples talking to each other about the future direction of education in Maskwacîs. Board governance in the wahkohtowin model involves the Chiefs Council, Elders Circle, Parent Advisory Circle, Student Leadership Program, and a yearly leadership summit with all Councils in Maskwacîs. Ensuring that a large number of people are involved in discussions about the schools will ensure venues for communication and that both a breadth and depth of relationships within the community are maintained.$^{52}$ Finally, the team that negotiated the agreement with the Federal Government ensured wahkohtowin is defined in the document along with other Cree terms such as Nehiyaw Pimatisiwin (Cree way of Life), Nehiyawewin (Cree Language) and Iyiniw Mamtohnehicikan (Cree thinking).

The numerous references to wahkohtowin were not the work of a single individual or small group but rather an expression of the centrality that wahkohtowin continues to play within everyday life in Maskwacîs. When wahkohtowin was 
combined with a political discourse that focused on the best interests of children, it created a powerful movement for change in the community.

The discourse of protecting treaty rights continued to be brought up within our deliberations about the process. Initially we described our actions as renewing the treaty relationship with the Federal government on the issue of education funding. As our Maskwacîs Declaration on Education states:

\begin{abstract}
Our treaty partners have not always respected the treaty relationship between us. The imposition of residential schools damaged the relationship between us. We feel that one of the primary avenues through which this relationship can be repaired is by properly funding education systems that are under our control and design. The Crown has a fiduciary duty, obligation and responsibility to provide unencumbered funding that allows Maskwacîs to educate our children in our own ways. ${ }^{53}$
\end{abstract}

Near the end of the process political leaders within Maskwacîs came to describe our task as implementing the treaty right to education. Former Chief of Montana First Nation Darrell Strongman stated that "[w]e are not giving up our treaty rights, what we are doing is figuring out how we pursue the Treaty right to education from our interpretation." ${ }^{54}$ Samson Cree Nation Councilor and MESC Board member Shannon Buffalo asserted that " $[\mathrm{w}]$ e're practicing the treaties, we're the ones implementing the treaties based on what we need." ${ }^{55}$ Finally, Wilton Littlechild, Grand Chief of Treaty Six stated "[y] ou are implementing the treaty right to education as leaders. After all, our children have treaty rights too." ${ }^{56}$

This led to a reframing of the MESC as being tasked with determining how the treaty right to education is implemented for Early Childhood to Grade 12 programs. What is most interesting to note here is that rather than focus on this issue to start within the communication strategy of the MESC, a focus on wahkohtowin and working in the best interests of children created the political space for people to articulate how we were pursuing a treaty right to education, completely independent of the MESC staff.

\section{Conclusion}

I hope a number of lessons learned from this process are readily apparent from recounting this story. First, the Nehiyaw legal concept of wahkohtowin was not embedded into the background assumptions of the political process we undertook but was front and centre within our decision-making process at multiple stages throughout the process. This changed the character of the process and likely played a major role in creating the conditions for political cooperation in a context where cooperation is notoriously difficult to achieve. Second, rather than the concept being ill-suited for an institutionalized setting like the Early Childhood to Grade 12 schooling system, wahkohtowin had its own discursive force that was able to alter the process within negotiations internal to Maskwacîs. These internal negotiations then allowed Maskwacîs to negotiate with the federal government from a position of strength. It is likely that without the centrality of wahkohtowin, the process could not have achieved the level of success and results it was able to achieve. From the standpoint of increasing the use of Indigenous law in Canada, my hope is that further attention can be paid to some of the explicit, productive, and fruitful ways that Indigenous legal concepts are being used and can be used within institutional settings.

\section{Endnotes}

* Instructor in Political Science and Native Studies at the University of Alberta. Currently completing his $\mathrm{PhD}$ in Political Science at the University of British Columbia. Matthew is Nehiyaw (Plains Cree), grew up in Maskwacîs and is a member of Ermineskin Cree Nation. He holds a BA Honours in Native Studies from the University of Alberta, and an MA in Indigenous Governance from the University of Victoria. He was a communication and governance advisor for the Maskwacîs Education Schools Commission from 2016 to 2018.

1 Hadley Friedland, "Reflective Frameworks: Methods for Accessing, Understanding and Applying Indigenous Laws" (2012) 11:1 Indigenous Law Journal 1 at 3.

2 Ibid at 6-7. 
3 RSC 1985, c I-5.

4 Online Cree Dictionary, sub verbo "wahkohtowin", online: <http://www.creedictionary.com/search/ index.php? $\mathrm{q}=$ wahkohtowin $\&$ scope $=1 \& \mathrm{cwr}=$ 59010>.

5 Harold Cardinal and Walter Hildebrandt, Treaty Elders of Saskatchewan: Our Dream is that our Peoples will One Day be Clearly Recognized as Nations (Calgary: University of Calgary Press, 2000) at 14.

6 Ibid.

7 Ibid.

8 Sylvia McAdam (Saysewahum), Nationhood Interrupted: Revitalizing nêhiyaw Legal Systems (Saskatoon: Purich Publishing, 2015).

9 Ibid at 63. See also 59-63.

10 Ibid at 47.

11 Maria Campbell, "We need to return to the principles of Wahkotowin" Eagle Feather News (November 2007), online: <http://aborigin. sasktelwebhosting.com/Resources/November2007.pdf> at 5.

12 See also BearPaw Legal, "Wahkohtowin: Cree Natural Law" (8 June 2016), online: YouTube <https://www.youtube.com/watch?v= NTXMrn2BZB0>.

13 See Anna Desmarais, " $U$ of A conference a 'turning point' for Indigenous law" CBC News (22 September 2017), online: <http://www. cbc.ca/news/canada/edmonton/university-ofalberta-reconciliation-wahkohtowin-1.4301833>; University of Alberta, Faculty of Law, "Out of the Classroom and Onto the Land: Introducing the Wahkohtowin Project" (17 November 2016), online: <https://www.ualberta.ca/law/news/mainnews/2016/november/the-wahkohtowinproject>; and Augustana Campus, "Wahkohtowin Lodge", online: <https://www.ualberta.ca/ augustana/services/aso/wahkohtowin-lodge $>$.

14 Spence Neighbourhood Association, "Wahkohtowin Strengthening Families Program" (28 August 2017), online: <http://www.spenceneighbourhood. org/wahkohtowin-strengthening-families- $>$.

15 Wahkohtown Child and Family Services, "Executive Summary", online: <http://www. wahkotowin.com>.

16 Saddle Lake Cree Nation, "The Saddle Lake Wahkohtowin Society", online: <http://www. saddlelake.ca/noflash/?page_id=350>.

17 Brenda Grundt, "Wahkohtowin Development LP to Invest \$4 Million in Hornepayne Sawmill \& Cogeneration Facility" wawa-news.com (3 August 2017), online: <https://wawa-news.com/index. php/2017/08/03/wahkohtowin-development- lp-to-invest-4-million-in-hornepayne-sawmillcogeneration-facility/>.

18 Brenda Macdougall, One of the Family: Metis Culture in Nineteenth-Century Northwestern Saskatchewan (Vancouver: UBC Press, 2010).

$19 \mathrm{Ibid}$ at 186.

20 Kathleen O'Reilly-Scanlon, Christine Crowe, and Angelina Weenie, "Pathways to understanding: 'Wahkohtowin' as a research methodology" (2004) 39:1 McGill Journal of Education 29 at 30 [citation omitted].

21 Theodore Binnema, Common \& Contested Ground: A Human and Environmental History of the Northwestern Plains (Norman: University of Oklahoma Press, 2001); Robert Alexander Innes, Elder Brother and the Law of the People: Contemporary Kinship and Cowessess First Nation (Winnipeg: University of Manitoba Press, 2013); Brenda MacDougall, "Wahkotowin: Family and Cultural Identity in Northwestern Saskatchewan Metis Communities" (2006) 87:3 Canadian Historical Review 431; Nicole St-Onge, Carolyn Podruchny, Brenda Macdougall, eds, Contours of a People: Metis Family, Mobility, and History (Norman: University of Oklahoma Press, 2012); Nicholas CP Vrooman, "The Whole Country Was... One Robe": The Little Shell Tribe's America (Marysville: Drumlummon Institute, 2013); Michael Witgen, An Infinity of Nations: How the Native New World Shaped Early North America (Philadelphia: University of Pennsylvania Press, 2012).

22 Treaty No 6, Her Majesty the Queen and the Plain and Wood Cree Indian and other Tribes at Fort Carlton, Fort Pitt and Battle River, 1876, online: <https://www.aadnc-aandc.gc.ca/eng/1100100028 710/1100100028783>.

23 Maskwacîs Education Schools Commission, "The Ermineskin Residential School Closes", online: <http://www.Maskwacîsed.ca/timeline/theermineskin-residential-school-closes/>.

24 Facing History and Ourselves, "Blue Quills", online: <https://www.facinghistory.org/stolenlives-indigenous-peoples-canada-and-indianresidential-schools/chapter-8/blue-quills $>$.

25 See Brian Wildcat, "History of Schools in Maskwacîs - Community Presentation", (November 2016). In 2003, only 10 students graduated from High School in Maskwacîs. In 2017, 56 students graduated from high school. In addition to increased enrollment and graduation, many successful programs have been developed and implemented within the schools. Doctor Shauna Bruno details two of these programs 
within Miyo Wahkohtowin Education Authority. One that focuses on how Miyo implemented restorative community-based practices in order to replace punitive approaches to discipline. The other focuses on an alternative High School program developed by Miyo that has seen a significant improvement in outcomes for students who have personal and education difficulties. See Shauna Bruno, "Nurturing Capacity: Building Community Success: Restorative Practices", online: <http://indspire.ca/nurturingcapacities/miyo-wahkohtowin-education-mwerestorative-practices/> and Shauna Bruno, "Nurturing Capacity: Building Community Success: Ehpewapahk Alternate School", online: $<$ http://indspire.ca/nurturing-capacities/miyowahkohtowin-education-ehpewapahk-alternateschool/>.

26 Maskwacîs Education Schools Commission, "History", online: <http://www.Maskwacîsed.ca/ history/>.

27 Personal communication with Brian Wildcat.

28 Wildcat, "History," supra note 26.

29 Maskwacîs Education Schools Commission, "Report to the Community" (January 2018) at 14.

30 Don Drummond and Ellen Kachuck Rosenbluth, "The Debate on First Nations Funding: Mind the Gap" (2013) School of Policy Studies, Queen's University Working Paper 49.

31 See Taiaiake Alfred, Peace, Power, Righteousness: An Indigenous Manifesto (Don Mills: Oxford University Press, 1999) at 25; Taiaiake Alfred, Wasáse: Indigenous Pathways of Action and Freedom (Toronto: University of Toronto Press, 2005) at 42; and Shiri Pasternak, Grounded Authority: The Algonquins of Barriere Lake against the State (Minneapolis: University of Minnesota Press, 2017) at 161-218.

32 See Behn v Moulton Contracting Ltd., 2013 SCC 26, [2013] 2 SCR 227.

332014 SCC 44, [2014] 2 SCR 257.

34 Ibid at para 25.

35 Ibid at para 26 citing Delgamuukw v British Columbia, [1997] 3 SCR 1010 at para 143, 153 $\operatorname{DLR}\left(4^{\text {th }}\right) 193$.

36 Michael McCrossan and Kiera L Ladner, "Eliminating Indigenous Jurisdictions: Federalism, the Supreme Court of Canada, and Territorial Rationalities of Power" (2016) 49:3 Canadian Journal of Political Science 411 at 412.

37 Ibid at 420.

38 Daniel Voth, "Her Majesty's Justice Be Done: Métis Legal Mobilization and the Pitfalls to Indigenous
Political Movement Building" (2016) 49:2 Canadian Journal of Political Science 243 at 244.

39 See the work of Robert Innes, "Multicultural Bands on the Northern Plains and the Notion of 'Tribal' History" in Robin Jarvis Brownlie and Valerie J Korinek, eds, Finding a Way to the Heart: Feminist Writings on Aboriginal and Women's History in Canada (Winnipeg: University of Manitoba Press, 2012) 122.

40 See Bonita Lawrence, "Real" Indians and Others: Mixed-Blood Urban Native Peoples and Indigenous Nationhood (Vancouver: UBC Press, 2004) and Pamela D Palmater, Beyond Blood: Rethinking Indigenous Identity (Saskatoon: Purich Publishing, 2011).

41 Joanne Barker, Native Acts: Law, Recognition, and Cultural Authenticity (Durham: Duke University Press, 2011) at 35-36.

42 Nellie Carlson, Linda Goyette, and Kathleen Steinhauer, Disinherited Generations: Our Struggle to Reclaim Treaty Rights for First Nations Women and Their Descendants (Edmonton: University of Alberta Press, 2013).

43 Government of Alberta, "Delegated First Nations Agencies", online: <http://www.humanservices. alberta.ca/family-community/15540.html .

44 Institute on Governance, "Revisiting RCAP Towards Reconciliation: The Future of Indigenous Governance" (January 2015), online: <https://iog. $\mathrm{ca} /$ docs/Revisiting-RCAP-Conference-Report. pdf $>$. The report also notes at 13 "that in some areas, the wording of the Indian Act, (recognizing each band as a nation) causes complexity where there could be progress by bands that are historically from the same nation/tribe."

45 Yale Belanger and David Newhouse, "Emerging from the Shadows: The Pursuit of Aboriginal SelfGovernment to Promote Aboriginal Well-Being" (2004) 24:1 Canadian Journal of Native Studies 129 at 166.

46 Matthew Wildcat, "Fearing social and cultural death: genocide and elimination in settler colonial Canada - an Indigenous perspective" (2015) 17:4 Journal of Genocide Research 391.

47 John F Leslie, Assimilation, Integration or Termination? The Development of Canadian Indian Policy, 1943-1963 (Doctoral Dissertation, Carleton University, 1999) [unpublished].

48 Maskwacîs Education Schools Commission, "Foundation Statements" (2016), in possession of the author.

49 Tracey Swampy, "Maskwacîs School Profile Video" (22 March 2017), online: YouTube <https://www. youtube.com/watch?v=ZvtWsHGgaMM>. 
50 Maskwacîs Education Schools Commission, "Maskwacîs Cree Declaration on Education" (2017), online: <http://www.Maskwacîsed.ca/ declaration/>.

51 Josephine Thompson Rain, online: Facebook <https://www.facebook.com/Maskwacîs Education/photos/a.1040321596089762.10737418 $28.1024541814334407 / 1262289530559633 /$ ?type $=$ 3\&theater $>$.

52 Maskwacîs Education Schools Commission, "Report to the Community" (2018), online: <http:// www.Maskwacîsed.ca/communityreport/> at 21 .

53 Maskwacîs Education Schools Commission, "Maskwacîs Cree Declaration on Education" (2017), online: <http://www.Maskwacîsed.ca/ declaration $/>$.

54 Maskwacîs Education Schools Commission, "Report to the Community" (2018), online: <http:// www.Maskwacîsed.ca/communityreport/> at 4 .

55 Ibid.

56 Ibid. 